\title{
Profesors Aleksandrs Janeks Professor Aleksandrs Janeks
}

\section{Uldis Alksnis, Ilgars Grosvalds}

\author{
Latvijas ķīmijas vēstures muzejs \\ Kronvalda bulv. 4, Rīga, LV-1010 \\ E-pasts: uldis.edvins@gmail.com
}

\begin{abstract}
Koloīdķīmijas aizsācējs Latvijā ir Aleksandrs Janeks (1891-1970). Pirmos zinātniskos darbus publicējis kopā ar savu skolotāju Pēteri fon Veimarnu. Latvijas Universitātē strādājis no 1919. līdz 1944. gadam. Publicējis mācību grāmatas: "Neorganiskā ķīmija" $(1922,1924)$ un "Dispersoidologijas pamati” (1925). Ar B. Jirgensonu pētījis alkoholu un sāļu ietekmi uz agara un želatīna šķīdumu viskozitāti, bet ar A. Šmitu - koloīdo šķīdumu pagatavošanas metodes. No 1950. gada strādājis ASV. Sākumā par Apdžona (Upjohn) firmas ķīmiķi, vēlāk par Kalamazū koledžas mācībspēku. Popularizējis Latvijā budismu.
\end{abstract}

Atslēgvārdi: A. Janeks, koloīdķīmija.

Aleksandrs Miķelis Janeks dzimis 1891. gada 28. novembrī Daugavpilī skolotāja Miķel̦a Janeka un vina sievas Bertas (dz. Bērne) gímenē. Pēc gada Janeku ǵimene pārcēlās uz Pēterburgu, kur tēvs strādāja par ierēdni un aktīvi piedalījās latviešu kopienas sabiedriskajā dzīvē. Aleksandrs mācījās Pēterburgas Sv. Katrīnas vidusskolā (1899-1909). To beidzot, iestājās Pēterburgas Universitātes Fizikas un matemātikas fakultātes Ķīmijas nodal̦ā. Augstskolu viņš absolvēja 1915. gada novembrī ar pirmās šķiras diplomu un cand. chem. grādu [1, 3, 7].

Pēterburgas Universitātē kolō̄dķīmiju mācīja Pēterburgas Kalnu institūta profesors Pēters fon Veimarns (1879-1940). A. Janeks ieinteresējās par koloīdḳīmiju. Skolotājam un skolniekam izveidojās cieša sadarbība. Vēl būdams Universitātes students, Janeks sarakstīja koloīdķīmijas mācību grāmatu [41]. Tā bija pirmā oriǵinālā koloīdķīmijas mācību grāmata krievu valodā. Ievadā A. Janeks norādīja, ka lielāko daḷu zinātniskā materiāla izklāstījis, pamatojoties uz sava skolotāja P. Veimarna teorijām. Sakarā ar to krievu koloīdķīmik̦is Nikolajs Peskovs (1880-1940), kas toreiz bija Maskavas Universitātes mācībspēks, rakstīja: "Pirmajās trīs nodaḷās Janeka kungs ļoti konsekventi un sistemātiski izvērš matērijas koloīdā stāvokḷa vispārīgu ainu, un droši var teikt, ka lasītājs, kas nav pazīstams ar šo parādību loku, gūs no grāmatas las̄̄šanas ļoti skaidru priekšstatu par koloīdiem .. Pavisam cits raksturs ir grāmatas otrajai, teorētiskajai daḷai. Balstoties vien̄̄gi uz Veimarna teorētiskajām koncepcijām, tā ir vienpusīga un tendencioza ..” [42]

Pēc Universitātes beigšanas A. Janeks 1916. gada janvārī sāka strādāt par dabaszinātņu un ǵeogrāfijas skolotāju Petrogradas evaṇgēeliski luteriskās Kristus glābēja baznīcas Komercizglītības izplatīšanas biedrības vīriešu astoņgadīgā komercskolā. 
Līdz ar to kā štata skolotājs viņš tika atbrīvots no iesaukšanas armijā un varēja paralēli skolotāja darbībai Petrogradas Kalnu institūtā prof. P. Veimarna laboratorijā gatavoties zinātniskajam darbam. Šajā laboratorijā A. Janeks strādāja no 1916. gada februāra līdz 1918. gada jūnijam. Tā rezultātā izstrādātas pirmās A. Janeka zinātniskās publikācijas (kopā ar P. Veimarnu) [43-45].

1918. gadā P. Veimarns kḷuva par Urālu Kalnu institūta (Jekaterinburgā) rektoru.

A. Janeku 1918. gada 7. jūnijā ievēlēja par šì institūta docentu, bet 1919. gada jūnijā viṇu apstiprināja par profesora vietas izpildītāju [7].

P. Veimarns Jekaterinburgā organizēja Urālu Kalnu institūta rakstu izdošanu. Tur bija iespiestas gan Janeka agrākās publikācijas [45-48], gan arī divi jauni raksti [49-50]. Rakstu par P. Veimarna zinātnisko darbību sakarā ar viņa 40 gadu jubileju [50] Janeks publicēja arī presē [51].

1919. gada jūnijā Urālu Kalnu institūtu evakuēja uz Vladivostoku un A. Janeku komandēja uz Vladivostokas Politehnisko institūtu par fizikālās ķīmijas profesora vietas izpildītāju. Šajā amatā vinsš strādāja no 1919. gada 1. jūlija līdz 1920. gada 1. martam.

1919. gada 22. septembrī A. Janeks salaulājās ar Mariju Kaupu, kuras dzimtene bija Igaunija [1].

1920. gada sākumā A. Janeks atsaucās uz Latvijas valdības aicinājumu, kurā Latvijas valdība lūdza augstskolu mācību spēkus atgriezties Latvijā un strādāt Latvijas Universitātē. 1920. gada martā A. Janeks un viṇa sieva ar tvaikoni, kurā uz Latviju brauca dal̦a no Imantas pulka, izbrauca no Vladivostokas un jūnija sākumā ieradās Latvijā. Viṇu ar 1920. gada 1. jūniju ieskaitīja Latvijas Universitātes mācību personāla sarakstā. 1920. gada septembrī A. Janeku ievēlēja par Ķīmijas fakultātes docentu, bet 1921. gada 4. maijā - par vecāko docentu [1, 20, 21].

A. Janeka pedagoǵiskā slodze bija: lekcijas dispersoidoloǵijā (kolōidķīmijāa) Ķīmijas fakultātes un Veterinārmedicīnas fakultātes studentiem, neorganiskajā ķīmijā Arhitektūras, Inženierzinātņu, Mehānikas un Tautsaimniecības un tiesību zinību fakultātes studentiem un ķīmijas vēsturē Ķīmijas fakultātes studentiem. A. Janeka pārziņā bija Dispersoidolog̣ijas (Kolō̄dķīmijas) laboratorija un Vispārīgās ķīmijas laboratorija inženieriem, mehāniķiem, ekonomistiem, arhitektiem un dabaszinātniekiem.

Dispersoidologijas (Kolō̄dķīmijas) laboratoriju A. Janeks Ķīmijas fakultātē izveidoja 1920. gada ruden̄̄. Sākumā tā bija tikai zinātniska laboratorija, bet no 1923. gada tajā mācījās arī studenti. Praktikums bija obligāts Ķīmijas fakultātes Farmācijas un Teorētiskās (programma B) nodaļas studentiem, Medicīnas, Veterinārmedic̄nas un Dabaszinātṇu fakultātes Fiziologijas nodaḷas studentiem [7, 20, $21,39]$.

1921. gada 4. maijā A. Janeku ievēlēja par vecāko docentu. Viņš ir bijis visai viduvējs lektors. Prof. H. Gode savās atmin̄ās raksta [33]: “.. Lasīja 2. klausītavā klusā balsī tāfelei, bet ne klausītājiem. Ar krītu neprata rīkoties, nepielika spēku un nekas nebija redzams .. Īstenībā viņa lekcijas bija vērtīgas, bija daudz materiāla, bet toreiz mēs nepratām viņa lielās zināšanas pienācīgu novērtēt".

Lai gan Janeks bija patīkama, jauneklīga izskata cilvēks, tomēr visai viduvējas materiāla izklāsta formas dēl viņa lekcijas studentu vidū nav bijušas populāras un 
studenti tās apmeklējuši ne visai kuplā skaitā. 30. gados Ķīmijas fakultātē bijis izplatīts šāds nostāsts. Kādam studentam, kas Janeka lekcijas nav apmeklējis, pienācis laiks kārtot attiecīgā priekšmeta eksāmenu. Students gājis uz Janeka kabinetu noskaidrot, kad varētu nokārtot eksāmenu. Janeks jau bijis pie kabineta durvīm piespraudis sarakstu, kad kuru eksāmenu pie viņa var kārtot. Students izvēlējies sev pieņemamu laiku, sagatavojies un gājis to nokārtot. Kabineta durvis nav bijušas aizslēgtas, bet kabinetā neviena nav bijis. Students apstājies koridorā pie loga pagaidīt, līdz profesors atgriežas. Un tad pēkšņi viņš ieraudzìjis, ka uz Janeka kabinetu nāk vēl viens jaunietis. Mūsu students jautājis: "Vai tu ar̄i pie Janeka?" Pienācējs tā kā sastomījies, bet tad atbildējis: "Jā, es arī pie Janeka." - "Klausies, es te tai Janeka grāmatā vienu vietu lāgā nesaprotu. Varbūt tu varētu man paskaidrot!" Pienācējs izklāstījis neskaidro vietu, pa brīžam uzdodot arī kādu jautājumu. Tā, stāvot pie loga, viņi pārrunājuši vairākus jautājumus. Un tad pēkšņi jaunpienācējs teicis: "Tu esi kārtīgi apguvis materiālu! Dod atzīmju grāmatiṇu. Es Tev lieku labu atzīmi." - Dullais, man taču jākārto eksāmens pie Janeka, nevis pie Tevis." - "Es jau esmu Janeks." [3]

Lai atvieglotu studentiem neorganiskās ķīmijas apgūšanu, A. Janeks jau pirmajā sava darba gadā (1920./21. m. g.) nodrukāja savu lekciju konspektus. Pēc gada tos iespieda tipogrāfijā [52], bet 1924. gadā [53] un 1930. gadā [54] šo grāmatu izdeva atkal.

1925. gadā latviešu valodā iznāca A. Janeka (arī A. Janēka) "Dispersoidologijas pamati” [55]. Šajā grāmatā bija pārtulkotas krievu izdevuma [41] pirmās trīs dal̦as, kuras N. Peskovs bija atzinis par labi uzrakstītām [42]. "Dispersoidoloǵijas pamatus" latviešu valodā pārtulkoja A. Janeka subasistents Bruno Jirgensons (1904-1982). Šī mācību grāmata bija pirmā kolōinķīmijas mācību grāmata latviešu valodā. To krievu valodā bija sarakstījis pēdējo kursu students A. Janeks un latviski tulkoja pēdējo kursu students B. Jirgensons.

20. gadu sākumā A. Janeks pievērsās budismam. Aizpildot Latvijas Augstskolas anketu, vin̄š 1920. gadā uz jautājumu "ticība" rakstījis "luterānis", 1921. gadā "pēc pārliecības - budists", 1922. gadā "budists" [1].

Pētot ritmisko kristalizāciju gelos (Lizeganga riņķus), A. Janeks bija ievērojis, ka nogulsnes veidojas ne tikai gelā, bet arī uz gela uzliktā šķīduma piliena virsmas. Šo parādību viņš uzskatīja par jaunu kapilārfenomenu un veltīja vairākus gadus tās izpētei [56-59].

1928. gada 9. decembrī A. Janeks ieguva LU ķīmijas doktora grādu, aizstāvot disertāciju Ein neues Kappilarphönomen (Jauns kapilārfenomens) [60].

1930. gada septembra sākumā komisija - prof. K. Blahers, prof. V. Fišers un prof. V. Svirlovskis - izvērtēja A. Janeka zinātnisko un pedagogiisko darbību un ieteica viņu ievēlēt par profesoru. 1930. gada 17. septembrī Ķīmijas fakultātes padome ievēlēja A. Janeku par profesoru vispārīgajā ķīmijā un fakultātes pārstāvi LU padomē [12, 20, 21, 39].

No 1932. gada līdz 1934. gadam A. Janeks bija Latvijas Biologijas biedrības prezidents. No 1935. gada līdz 1940. gadam - Latviešu un franču tuvināšanās biedrības priekšnieks. 1935. gadā piedalījās Grenobles Universitātes 600 gadu jubilejā. 1937. gadā tika ievēlēts par vicepriekšnieku Latvijas komitejā Parīzes izstādes norises sekmēšanai. 
Janeku 1937. gada 17. novembrī apbalvoja ar Triju Zvaigžņu 3. šķiras ordeni, bet 1938. gada 24. augustā - ar Francijas Goda leǵiona 4. šķiras ordeni [21]. Ar Latvijas Valsts prezidenta 1938. gada 24. augusta 156. rīkojumu viṇam atḷauts nēsāt šo ārvalsts ordeni.

Vācu okupācijas gados A. Janeks turpināja pasniedzēja darbu un publicēja elementu periodiskās sistēmas savu variantu [89]. Sekmīgais A. Janeka zinātniskais un pedagoǵiskais darbs pārtrūka Otrā pasaules kara beigu posmā.

1944. gada 16. augustā ar "Universitātes Rīgā” (LU nosaukums nacistiskās okupācijas laikā) rektora rīkojumu Nr. 33/106 viņam piešḳīra bezalgas atvaļinājumu uz nenoteiktu laiku. Frontei tuvojoties Rīgai, viņš ar kundzi Mariju 1944. gada augustā pārcēlās uz Vāciju. Strādāja Mārburgas Universitātes Fizikālās k̦īmijas laboratorijā. Zinātniskās darbības turpināšanai saṇēma Aleksandra fon Humbolta fonda stipendiju. Karam beidzoties, strādāja ASV armijas daḷā par instruktoru un štāba virsnieku skolā par tulku no vācu un franču valodas uz angḷ valodu.

1950. gada maijā kopā ar kundzi pārcēēās uz ASV un apmetās uz dzivi Kalamazū, Mičiganas štatā. Tur A. Janeks līdz 1958. gadam strādāja par k̦īmiķi Upjohn firmā un mācīja krievu un vācu valodu Kalamazū koledžā. Vēlāk šajā koledžā lasīja arī lekcijas par vispārīgiem kultūrvēsturiskiem jautājumiem. Miris 1970. gada 21. oktobrī Kalamazū [29, 30].

20. gadsimta 20. gados A. Janeks ne tikai pētījis ritmisko kristalizāciju [56-60], bet arī pievērsies vairākiem citiem kolō̄dķīmijas jautājumiem. Konstruējis savu elektroforēzes aparāta variantu [63], pētījis tabakas ekstraktu izmantošanu koloīdo šksīdumu ieguvei [64]. 1923. gadā A. Janeka vadībā zinātnisko darbu sāk veikt Bruno Jirgensons (1904-1982). Vinšs pēta organisko vielu ietekmi uz solu stabilitāti. Pirmās kopīgās publikācijas iespiestas 1927. gadā [65-68]. Tie ir pētījumi par neorganisko vielu koloīdajiem šķīdumiem. 1926. gadā B. Jirgensons beidza Ķīmijas fakultāti un pievērsās lielmolekulāro vielu šķīdumu pētīšanai, kas viṇu interesēja vairāk. Pirmās publikācijas šajā virzienā arī tapušas A. Janeka vadībā [69-71].

Par savu šefu B. Jirgensons raksta [36]: "Lai gan docenta Janeka specialitāte skaitījās koloīdķīmija (dispersoidoloǵija) daudz stundu viņa darba istabā mums pagāja filozofiska rakstura diskusijās. Viņš lasīja diezgan interesanti, taču mani vēl vairāk interesēja koloīdķīmija [...]. Nekas nopietnāks eksperimentāli tomēr vēl nevarēja tikt pasākts studenta un subasistenta pienākumu dēḷ. Sekojot šefa Janeka norādījumiem, bija jāpieturas pie neorganiskiem koloīdiem [...]. Patstāvīgus pētījumus par organisko biokoloīdu koagulāciju 1926./27. g. turpināju ar lielu enerğiju un labām sekmēm. Ap to laiku šefs Janeks bieži slimoja, mazāk interesējās par manu darbību, tā kā varēju brīvi izvēlēties darba virzienu un plānu [..]. 1927. gadā publicēti pirmie darbi, vispirms kopā ar Janeku LU rakstos un vācu žurnālā KolloidZeitschrift. Nedaudz vēlāk sāka nākt klajā arī pastāvīgi veiktie darbi par biokoloīdu koagulāciju ar organiskām vielām un sāliem. Pirmie mēǵinājumi iesniegt doktora disertācijas metu beidzās nesekmīgi, jo Janeks tos noraidīja. Un kad Janeka katedrai 1928. gadā tika piešksirta asistentūra, mani neavansēja par asistentu, bet pieṇēma kolēgi inž. ķīmiķi A. Šmidtu. Janeks bija apvainojies arī par to, ka 1927. gadā no Lauksaimniecības fakultātes bija ienācis priekšlikums, lai viņa neķīmiķiem lasīto ķīmijas kursu sadala, t. i., lai tautsaimniekiem ķīmiju dotu man, no tā, protams, nekas neiznāca." 
1926. gadā Janeka vadībā zinātniskos pētījumus sāka veikt Arvīds Šmits (1894-1968). Tie apkopoti četrās publikācijās [72-75].

30. gadu pirmajā pusē A. Janeks veica pētījumus par sēra solu ieguves metodēm [76-78].

Janeks daudz cel̦oja. Sevišksi bija iecienījis Franciju, kur viņam bija izveidojušies kontakti ar franču zinātniekiem un universitātēm Parīzē un Grenoblē. Cel̦ošanu atviegloja plašās valodas zināšanas. Latvijas Universitātes aptaujas lapā 1942. gada 29. aprīlī viņš norādījis, ka labi pārvalda latviešu, vācu, franču, angl̦u un krievu valodu, vāji - k̦īniešu un itāḷu.

Janeks tulkojis no franču valodas A. L. Lešateljē brošūru "Izcilu personību izveidošanās zinātnē un tehnikā" [79] un E. Pikarda "Skats uz zinātṇu un fizikālo teoriju vēsturi" [80], kā arī publicējis trīs rakstus, veltītus franču kultūrai un zinātnei [81-83], kā arī rakstus par zinātniekiem Paulu Šucenbergeru [83] un Andrē Mar̄i Ampēru [84, 85]. 1931. gadā A. Janeku kā Latvijas Universitātes pārstāvi sūtīja uz Francijas koledžas 400 gadu svinībām.

No 1932. līdz 1934. gadam Janeks pildīja Bioloǵijas biedrības prezidenta pienākumus. Bija Latvijas Ķīmijas biedrības biedrs un tās pēdējais priekšsēè̄tājs (1934-1944). Arī biedrs biedrībās Philosophia (Belgradā), Kolloid-Geselschaft (Leipcigā), Deutsche Chemische Gesellschaft (Berlīnē).

20. gadu sākumā A. Janeks aizrāvās ar budismu un publicēja par šo tēmu vairāk nekā 10 rakstus [91-103]. 30. gadu sākumā viņu arvien vairāk saistīja filozofijas jautājumi [104-113].

A. Janeka filozofiskos uzskatus izvērtējis pazīstamais filozofijas profesors Pauls Jurevičs [15]. Janeks izteic uzskatu: "kā parastā, tā zinātniskā uztvere stipri pārveido īsto pasaules ainu tādā ziṇā, ka tas, kas mums dots ir tikai vairāk vai mazāk kondensēts un dots uz reizi vienā momentā. [..] Pretim šim šksitumam Janeks nostāda īstenību, kas atklājas no viedokḷa, ko viņšs sauc par epallēlisku. [..] Matērija, elektroni, atomi, tāpat dvēsele - viss tas ir tikai "kondensācija", izskaidrošanas fikcijas, bet nekas reāls, ja vispār īstas esamības pasaulē nemaz nav, bet absolūtais ir - dotību nepārredzamā laicīgā secība, nerimstoša visa plūsma".

Izsakām pateicību 1999. gada LU K̦īmijas fakultātes absolventam Viesturam Frišfelda kungam par diplomdarbā savākto plašo datu klāstu par A. Janeku un viņa darbību.

\section{VĒRES}

\section{Par A. Janeku}

1. Janeks Aleksandrs. LVVA, 7427. f., 13. apr., 670. 1., 116 lpp.

2. Ķīmijas fak. zinātniskais un pedagogiskais personāls. Sast. A. Ķešāns, 1938, 23. lpp. Latvijas ķīmijas vēst. muzejs. 12. krāj., 3761. lieta.

3. Janeks Aleksandrs un viña darbi koloīdķīmijā. V. Frišfelda bakalaura darbs. Rīga, 1999. $45 \mathrm{lpp}$.

4. Janeks K. Janeku ciltskoks. Rīga: Lauku apgāds, 1992, 15. lpp.

5. Apmeklētājs. Ko dod mums budisms? [Doc. A. Janeka 19. febr. lekcijas atreferējums.] Students, 1924, 7. marts. 
6. Dr. chem. Aleksandrs Janeks [A. Janeka doktora disert. aizstāvēšana]. Students, 1929, 24. janv.

7. Latvijas Universitāte. 1919.-1929. Rīga: LU, 1929, 118.-119. lpp.

8. Padome 8. oktobrī ievēlēja doc. A. Janeku par prof. Ķīmijas fak. Universitas, 1930, 15. okt., 12. lpp.

9. Jaunievēlētie profesori Ķīmijas fak. Students, 1930, 27. okt.

10. Latviešu konversācijas vārdnīca, 7. sēj. [A. Janeks]. Rīga: A. Gulbja apg., 1931, 13869.-13870. sleja.

11. Jurevičs P. Filozofiskā doma latviešu garīgā dzīvē. Latvieši II. Rīga: Valters un Rapa, 1932, 327.-344. lpp.

12. Ķešāns A. Latvija. Latvju zinātne, ķīmija. No: Latviešu konversācijas vārdnīca, 11. sēj. Rīga: A. Gulbja apg. 1934/35, 22457.-22463. sleja.

13. Latvijas Biolog̣ijas biedrības gada sapulce notika 7. febr. Revīzijas komisijā ievēlēti prof. A. Janeks u. c. Universitas, 1936, 20. febr., 67. lpp.

14. Ampēra piemiņas akts notiks 26. maijā, kuru rīko matemātikas un dabas zinātņu fak. Priekšlasījumu noturēs prof. A. Janeks. Universitas, 1936, 25. maijs, 164. lpp.

15. Jurevičs P. Filozofija. Latviešu literatūras vēsture. Rīga: Literatūra, 1937, 420.-421. lpp.

16. Latvju mazā enciklopēdija. 1. sēj. Rīga: Grāmatu draugs, 1938, 1064. sleja.

17. Straumanis M. Ķīmija. No: Zinātne Tēvzemei. 1918.-1938. Rīga: LU, 1938, 159.-160. lpp.

18. Kultūras fonda pabalsti. Students, 1838, 5. jūn., 477. lpp.

19. Janeks Aleksandrs Miķelis. Es viņu pazìstu. Latviešu biogrāfiskā vārdnīca. Rīga: Biogrāfiskais apgāds, 1939, 209.-210. lpp.

20. Ķešāns A. Ķ̄̄mijas fakultāte. Latvijas Universitāte divdesmit gados. 1919-1939. I daļa. Rīga: LU, 1939, 390. lpp.

21. Latvijas Universitāte divdesmit gados. 1919-1939. I daļa. Rīga: LU, 1939, 169.-170. lpp.

22. Universitātes padomes lēmumi. Students, 1939, 30. apr.

23. Latvju enciklopēdija. 1. sēj. Stokholma: Trīs zvaigznes, 1950/1951, 511. lpp.

24. [Jirgensons B.]. Prof. Dr. chem. A. Janekam 70 gadi. Technikas apskats, 1961, Nr. 32, 22. lpp.

25. Stradin̦š J. Ķìmija Latvijas Universitātēe (1919-1940). Par tehnikas vēsturi Latvijas PSR. VI. Rīga: LPSR ZA izdevn., 1964, 16. lpp.

26. Prof. Dr. chem. Janekam Aleksandram 75. Technikas apskats, 1966, Nr. 52, 22. 1pp.

27. Johansons A. Rīgas svārki mugurāa. Bruklina: Grāmatu Draugs, 1966, 197. lpp.; Rīga: Daugava, 2000, 194. lpp.

28. Sakse A. Dvēseles naktī. Rīga: Liesma, 1969, 58.-60. lpp.

29. MES [Straumanis M. E.]. Prof. Dr. chem. A. Janeks aizsaulē. Technikas apskats, 1971, Nr. 62, 17.-18. lpp.

30. Alksnis A. Latvijas Universitātes Medicīnas fakultāte. Universitas, 1971, Nr. 27, 8. lpp.

31. Kazerovskis K. Fakultāte ar raženām darba tradīcijām. Latvijas Universitātes Ķīmijas fakultātes Ķīmijas nodą̧a. Universitas, 1980, Nr. 45, 31.-33. lpp.

32. Latvju enciklopēdija. 1962-1982. 2. sēj. Rockville: Amerikas latviešu apvienības institūts, 1985, 2. lpp.

33. Gode H. Atmiņas par Ķīmijas fakultāti. Rīga, 1988, 81 lpp., rokraksts.

34. Ozoliṇa V. Ķīmiķis - pedagogs, zinātnieks un filozofs Aleksandrs Janeks (1891-1970). Izglìtība, 1991, 28. dec., 7. lpp. 
35. Grosvalds I. Latvijas Universitātes ķīmiķu ceļi un likteņi pasaulē. Rīgas Tehniskās universitātes vēstures lappuses. 9. sēj. Rīga: RTU, 1992, 167.-168. lpp.

36. Jirgensons B. Studiju gaita un darbs Latvijas Universitātes Ķīmijas fakultātē 1924.-1939. Acta Medico Historica Rigensia. 21. sēj. Rīga: P. Stradiņa Medicīnas vēstures muzejs, 1994, 301.-315. lpp.

37. Raņķis G. Eksaktā zinātne kultūras vēsturēe. Rīga: Liesma, 1999, 418.-420. lpp.

38. Augstākās tehniskās izglītības vēsture Latvijā. 2. dalăa. Rīga: RTU, 2004, 438. lpp.

39. Grosvalds I., Alksnis U., Meirovics I., Ruplis A. Ķīmija Latvijas Universitātē 19191944. Rīga: Latv. ķīm. vēst. muzejs, 2005, 151. lpp.

40. Latvijas enciklopēdija. 3. sēj. Rīga: V. Belokonsa izdevn., 2005, 115.-116. lpp.

\section{A. Janeka publikācijas}

41. Янекъ А. Краткій учебникъ дисперсоидологии. Петроград, К. Л. Рикер, 1915, 248 с.

42. Песков Н. П., Янекъ А. - Краткий учебник дисперсоидологии. Вестник прикладной химии и химической технологии, 1916, № 1, с. 64-65.

43. Веймарнъ П. П. фонъ, Янекъ А. Отношение положительных и отрицательных дисперсоидовъ къ встряхиванию съ различными практически нерастворимыми веществами. Русск. хим. общ., 1916, № 48, с. 1044.

44. Веймарнъ П. П. фонъ, Янекъ А. Определение зарядов у дисперсоидовъ. Русск. хим. общ., 1916, № 48, с. 1045.

45. Веймарнъ П. П. фонъ, Янекъ А. О процессе “растворенія” хлорного золота въ ароматических углеводородахъ. Русск. хим. общ., 1916, № 48, с. 1060.

46. Веймарнъ П. П. фонъ, Янекъ А. Отношение положительных и отрицательных дисперсоидовъ къ встряхиванию съ различными практически нерастворимыми веществами. Известия Уральского Горного института, 1918/19, № 1/3, с. 112.

47. Веймарнъ П. П. фонъ, Янекъ А. Определение зарядов у дисперсоидовъ. Известия Уральского Горного института, 1918/19, № 1/3, с. 113.

48. Веймарнъ П. П. фонъ, Янекъ А. О процессе “растворенія" хлорного золота въ ароматических углеводородахъ. Известия Уральского Горного института, 1918/19, № 1/3, c. 127.

49. Янекъ А. Коагуляция дисперсоидныхъ растворовъ на поверхностяхъ раздела соприкасающихся фазъ. Известия Уральского Горного института, 1918/19, № 1, с. 45.

50. Янекъ А. Характеристика научной деятельности П. П. фонъ Веймарна. Известия Уральского Горного института, 1918/19, № 1/4, с. 28.

51. Янекъ А. Характеристика научной деятельности П. П. фонъ Веймарна. Молодая Русь, 1919, май, с. 30-32.

52. Janeks A. Neorganiskā ķimija. Teorētiskā daļa un nemetāli (pēc manām lekcijām Latvijas Universitātē). 2. papild. izd. Rīga: A. Ošinšs, R. Mantinieks, 1921/22. 199 lpp.

53. Janeks A. Neorganiskā ķīmija. 1. d., 3. izd. Rīga: A. Ošinš̌, R. Mantinieks, 1924. 226 lpp.

54. Janeks A. Neorganiskā ķīmija. 4. izd. Rīga: A. Ošiņš, R. Mantinieks, 1930. 234 lpp.

55. Janēks A. Dispersoidologijas pamati. 2. papild. izdev. I dal̆a. Koloidu problèma un koloìdie šķìdumi. Rīga: F. Vītuma izd., 1925. 101 lpp.

56. Janek A. Rhythmisch gebänderte Niederschlagshäutchen auf Flüssigkeitsoberflächen. I. Kolloid-Zeitschrift, 1923, 32, Heft 4, S. 252-253.

57. Janek A. Rhythmisch gebänderte Niederschlagshäutchen auf Flüssigkeitsoberflächen. II. Kolloid-Zeitschrift, 1923, 33, Heft 2, S. 86-89. 
58. Janek A. Ein neues Kappilarphönomen. Kolloidchemische Beihefte, 1927, 24, Heft 10-12, S. 418-448.

59. Janek A. Ein neues Kappilarphönomen. Acta Universitatis Latviensis, 1927, Nr. 17, 681-717.

60. Janek A. Ein neues Kappilarphönomen. Rīga, 1927, 64 S.; LĶVM 59. krāj., 2. apr.

61. LVVA, 4427. f., 7. apr., 55. 1. Ziṇas par LU un tās biedrībām, 1943. g.

62. Rīgas Tehniskās universitātes Materiālzinātnes un lietišşās ķīmijas fakultātei 150. Rīga: RTU, 2013, 167. lpp.

63. Janek A. Überführungsapparat. Kolloid-Zeitschrift, 1924, 39, S. 104.

64. Janek A. Tabaklauge als Reduktionsmittel zur Herstellung von Solen. Kolloid-Zeitschri$f t, 1927,41$, Heft 3, S. 242-243.

65. Janek A., Jirgensons B. Einflu $\beta$ der Alkohole auf die Koagulation von dispersoiden Lösungen. Kolloid-Zeitschrift, 1927, 41, Heft 1, S. 40-46.

66. Janek A., Jirgensons Br. Sensibilisierende und stabilisurende Wirkung der Haut auf kolloide Lösungen. Biochemische-Zeitschrift, 1927, 180, Heft 1/3, S. 193-200.

67. Janeks A., Jirgensons Br. Alkoholu iespaids uz dispersoīdu koagulāciju. Acta Universitatis Latviensis, 1927, 16, 509.-544. 1pp.

68. Janeks A., Jirgensons B. Dažu mazšķ̄istošu organisko vielu iespaids uz elektrolītkoagulāciju. Latvijas Farmaceitu žurnāls, 1928, 5, 149.-152. lpp.

69. Jirgensons Br. (Unter Leitung von A. Janek). Die Koagulation des Hämoglobins in Gegenwart von Alkoholen I. Kolloid- Zeitschrift, 1927, 41, Heft 4, S. 331-334.

70. Jirgensons Br. (Unter Leitung von A. Janek). Die Koagulation des Hämoglobins in Gegenwart von Alkoholen II. Kolloid- Zeitschrift, 1927, 42, S. 59.

71. Jirgensons Br. (Unter Leitung von A. Janek). Die Koagulation des Hämoglobins in Gegenwart von Alkoholen III. Kolloid-Zeitschrift, 1927, 44, Heft 1, S. 76-79.

72. Janek A., Schmidt A. Überführung der dispersen Phase aus einem Dispersions-mittel in ein anderes durch Entmischung. I. Die Erscheinung und der Einflu $\beta$ der Hofmeisterschen Iononenreihe. Kolloid-Zeitschrift, 1930, 52, Heft 3, S. 280-288.

73. Janek A., Schmidt A. Die Koagulation von Kolloiden durch Emulsionen die sich bei Temperaturänderung bilden. Kolloid-Zeitschrift, 1930, 50, S. 263-265.

74. Janek A., Schmidt A. Kolloide Lösungen bei der Hydrolyse von Zerisulfat. KolloidZeitschrift, 1933, 65, Heft 3, S. 295-297.

75. Janek A., Schmidt A. Überführung der dispersen Phase aus einem Dispersions-mittel in ein anderes durch Entmischung. II. Kolloid-Zeitschrift, 1934, 66, S. 296-302.

76. Janek A. Ein neues Verfahren zur Herstelbung von Schwefelsolen. Kolloid-Zeitschrift, 1933, 64, Heft 1, S. 31-32.

77. Janek A. Kolloide Schwefellösungen durch Einwirkung von Schwefelsolen. KolloidZeitschrift, 1933, 65, Heft 1, S. 65.

78. Janeks A. Divas jaunas koloīdā sēra pagatavošanas metodes. Latvijas Farmaceitu žur$n \bar{a} l s, 1933$, Nr. 8, 355.-356. 1pp.

79. Prof. Le Chatelier. Izcilu personību izveidošanās zinātnē un tehnikā. Rīga, 1934. 15 lpp.

80. Picard E. Skats uz zinātņu un fizikālo teoriju vēsturi. Kurzemes vārds, 1937. 43 lpp.

81. Janeks A. Francijas kultūras gaisma. Students, 1931, 6. marts.

82. Janeks A. Francijas gara kultūra. Burtnieks, 1936, Nr. 1, 29.-39. lpp.

83. Janeks A. Paul Schutzenberger l'homme at l'Oeuvre. Acta Universitatis Latviensis, 1930, Nr. 6, 139.-144. lpp. 
84. Janeks A. A. M. Ampere, l'Homme et l'Oeuvre. Latvijas Farmaceitu Žurnāls, 1937, Nr. 7, 310.-313. 1pp.

85. Janeks A. A. M. Ampere, l'Homme et l'Oeuvre. Rīga: Latvijas Farmaceitu biedrība, 1937, 6. 1pp.

86. Janeks A. College de France 400 gadu pastāvēšanas svētki Parīzē. Latvijas Farmaceitu Žurnāls, 1931, Nr. 12, 391.-396. lpp.

87. Janeks A. College de France 400 gadu pastāvēšanas svētki Parīzē. Rīga: Grāmatrūpnieks, 1931. 8 lpp.

88. Janeks A. College de France. Students, 1932, 5. febr.

89. Janeks A. Elementu periodiskā sistèma. Rīga, autora izdevums, 1943, 3 lpp.

90. Janek A. Zur Statistik der Wertigkeiten. Zeitschrift für anorg. Chemie, 1944, Nr. 48, S. 354.

91. Janeks A. Budas mācība. Valdības Vēstnesis, 1924, Nr. 62.

92. Janeks A. Par Budas mācība. Valdības Vēstnesis, 1924, Nr. 261.

93. Janeks A. Ko dod mums budisms? Students, 1924, Nr. 22.

94. Janeks A. Budisms (lekcija). Rīgas Ziņas, 1924, Nr. 45.

95. Janeks A. Kā Tenisons maldina publiku? Rìgas Ziņas, 1924, Nr. 45.

96. Janeks A. Buddas mācību pamati. Rīga: F. Vītuma izdevums, 1925. 88 lpp.

97. Janeks A. Dzīve un reliǵija. Rīga: F. Vītuma izdevums, 1925. 48 lpp.

98. Janeks A. Kāds vārds par "jauno reliǵiju”. Pirmdiena, 1925, Nr. 29, 32.

99. Janek A. Das Problem des Buddha. Der Phad III, 1925, S. 220.

100. Janek A. Nibbana - die höchste Kultur. Der Phad IV, 1926, S. 18.

101. Janek A. Ecce mundus. Der Phad IV, 1926, S. 91.

102. Janek A. Die Religion Buddhas. Der Phad IV, 1926, S. 132, 151.

103. Janek A. Hast du des Entstandenen Nichtigkeit erkannt, so bist du auch Erkenner des Ewigen goworden. Der Phad V, 1928, S. 6.

104. Janeks A. Kultūras ceḷi un Eiropas lielā tradīcija. Students, 1931, 8. maijs.

105. Janeks A. Nezūdamības princips ķīmijā un tā vispārējā kritika. Daba un Zinātne, 1935, Nr. 4, 5. lpp.

106. Janeks A. Die Realität vom Standpunkt des Epallelismus. Latvijas Farmaceitu Žurnāls, 1935, Nr. 4, 150.-155. lpp.; Nr. 5, 190.-196. lpp.; Nr. 6, 230.-234. lpp.

107. Janek A. Die Realität vom Stanpunkt des Epallelismus. Rīga: Grāmatrūpnieks, 1935, 1935, 17 lpp.

108. Janek A. Die Realität vom Stanpunkt des Epallelismus. Burtnieks, 1936, Nr. 3.

109. Janeks A. Der Epallelismus und die naturwissenschaftliche Forschung. Latvijas Farmaceitu Žurnāls, 1937, Nr. 4, 167.-172. 1pp.; Nr. 5, 215.-219. 1pp.; Nr. 6, 247.-255. lpp.

110. Janeks A. Der Epallelismus und die naturwissenschaftliche Forschung. Rīga: Latvijas Farmaceitu biedrība, 1937, 22. 1pp.

111. Janeks A. Kurze Übersicht über den epallelistschen Standpunkt und seine Stellung zur Frage über das Wesen der naturwissenschaftlichen Forschung. Latvijas Farmaceitu Žurnāls, 1937, Nr. 7, 310.-313. 1pp.

112. Janeks A. Fizikālās pasaules izpratnes būtība (Epalēliskā viedokḷa pamatojums). Rīga: Latvijas Farmaceitu biedrība, 1939, 20. 1pp.

113. Janeks A. Fizikālā pasaule un zinātne. Rīga, autora izdevums, 1940. 60 lpp. 


\section{Summary}

Alexander Janek (1891-1970) is the founder of colloid chemistry in Latvia. He published his first scientific works together with his teacher Peter von Weimarn, and worked at the University of Latvia from 1919 to 1944. Ha has published textbooks "Inorganic chemistry" (1922, 1924) and "Fundamentals of dispersion" (1925). Together with B. Jirgenson, he studied the effects of alcohol and salts on viscosity of agar and gelatin solutions, but with A. Shmit - the preparation methods of colloidal solutions. Since 1950 he worked in USA - initially as a chemist in the company "Upjohn", and later as a lecturer in Kalamazoo College. Popularized Buddhism in Latvia.

Keywords: A. Janek, colloid chemistry. 